\title{
Prediksi Kebangkrutan Menggunakan Model Grover, Zmijewski, \& Altman Pada LPD di Kabupaten Gianyar Tahun 2013-2017
}

\author{
Ida Ayu Pradnyandhari Dewi ${ }^{1}$ \\ Fakultas Ekonomi dan Bisnis \\ Universitas Udayana, Indonesia. \\ Email: pradnyandhari02@gmail.com
}

\author{
I Wayan Ramantha ${ }^{2}$ \\ Fakultas Ekonomi dan Bisnis \\ Universitas Udayana, Indonesia.
}

\begin{abstract}
ABSTRAK
LPD se-Kabupaten Gianyar memiliki aset sebesar Rp3,6 triliun namun pada tahun 2013 sampai tahun 2017 terdapat LPD yang tidak beroperasi sebanyak 41 LPD. Penelitian ini menggunkan alternatif lain selain CAMEL dan menentukan model mana yang memiliki keakuratan antara model grover, zmijewski dan altman dalam memprediksi kebangkrutan LPD. Hasil penelitian menunjukan bahwa pada tahun 2013, 2014, dan 2016 terdapat 2 LPD dan tahun 2015 dan 2017 terdapat 1 LPD yang diprediksi bangkrut menggunakan model grover. Tahun 2013 terdapat 78 LPD, tahun 2014 dan 2017 terdapat 76 LPD dan tahun 2016 terdapat 77 LPD yang diprediksi bangkrut menggunakan model zmijewski. Tahun 2013-2017 tidak terdapat LPD yang diprediksi bangkrut menggunakan model altman. Model terakurat yang dapat digunakan dalam memprediksi kebangkrutan dengan membandingkan penilaian manajemen pada CAMEL adalah model altman dengan persentase rata-rata akurasi $91,87 \%$.
\end{abstract}

Kata Kunci: Kebangkrutan; Model Grover; Model Zmijewski; Model Altman.

Bankruptcy Prediction Using Grover, Zmijewski, and Altman Models in LPD in Gianyar Regency in 2013-2017

\begin{abstract}
LPDs throughout the Gianyar Regency have assets of Rp. 3.6 trillion, but from 2013 to 2017 there were 41 non-operating. This study uses other alternatives besides CAMEL and determines which model has the accuracy between the grover, zmijewski and altman models in predicting LPD bankruptcy. The results showed that in 2013, 2014, and 2016 there were 2 LPDs and in 2015 and 2017 there were 1 LPDs that were predictet bankrupt using the grover model. In 2013 there were 78 LPDs, in 2014 and 2017 there were 76 LPDs and in 2016 there were 77 LPDs that were predicted bankrupt using the zmijewski model. In 2013-2017 there were not LPDs that were predicted bankrupt using the altman model. The most accurate model that can be used in predicting bankruptcy by comparing management ratings on CAMEL is the altman model with an average percentage accuracy of $91.87 \%$.
\end{abstract}

Keywords: Bankruptcy; Grover Model; Zmijewski Model; Altman Model.

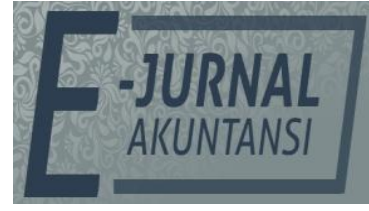

E-JA

e-Jurnal Akuntansi e-ISSN 2302-8556

Vol. 29 No. 3

Denpasar, Desember 2019

Hal. 1041-1054

Artikel masuk: 10 Oktober 2019

Tanggal diterima: 8 November 2019 


\section{PENDAHULUAN}

LPD dirintis dikarenakan pada Februari 1984, Departemen Dalam Negeri mengadakan seminar mengenai kredit pedesaan di Semarang. Hasil seminar tersebut, Gubernur Bali mengambil langkah cepat dengan mendirikan lembaga keuangan pedesaan yang disebut dengan LPD. Sebagai sarana mengembangakan ekonomi desa adatnya, Gubernur Bali Ida Bagus Mantra mendirikan LPD pada tahun 1984 yang memiliki peran sebagai sumber pendapatan desa adat yang mampu membantu masyarakat untuk mensejahterakan masayarakat pedesaan melalu menyimpan dana, memberikan dana untuk modal usaha maupun kegiatan lainnya, yang dimana hasil dari sisa hasil usaha yang didapatkan akan dikembalikan lagi kepada desa adat untuk kegiatan desa adat setempat.

LPD memiliki ketentuan dan aturan yang melandasi berdirinya LPD adalah Keputusan Gurbernur Daerah Bali Tingkat I Bali tanggal 1 November 1984 Nomor 972 yang beberapakali disempurnakan hingga saat ini menjadi Perda Bali Nomor 3 Tahun 2017. LPD pada tahun 1984 hanya terdapat 8 LPD di Bali. Tahun 1985 terdapat 24 LPD, tahun 1986 terdapat 71 LPD. Empat tahun kemudian menjadi 341 LPD pada tahun 1990. Perkembangan LPD terus meningkat, pada tahun 1995 sudah terdapat 849 LPD. Tahun 2000 terdapat 930 LPD, pada tahun 2005 terdapat 1.340 LPD dan pada tahun 2016 total LPD yang terdapat di Bali adalah 1.433 LPD. Perkembangan LPD dari waktu ke waktu menunjukan keberadaan LPD memang dibutukan krama desa.

Pesatnya perkembangan LPD perlu diawasi sehingga pada Perda Bali Nomor 3 Tahun 2017 tentang LPD mengharuskan, prajuru LPD atau pelaksana operasional LPD wajib menyampaikan laporan kegiatan perkembangan keuangan dan kinerja LPD kepada bendesa/kepala desa dan Lembaga Pemberdayaan Lembaga Perkreditan Desa (LPLPD) setiap 1 bulan, 3 bulan, dan tahunan dengan menyampaikan laporan tahunan paling lambat 3 bulan setelah tahun buku LPD berakhir. LPD juga diwajibkan melakukan audit 1 kali dalam setahun yang dimana audit yang dimaksud adalah panureka/badan pengawasan terhadap pengelolaan LPD, LPLPD, dan/atau Lembaga Auditor yang ditunjuk, hal tersebut meminimalisir kesalahan dalam pengelolaan sehingga mrnghindari mengalami kegagalan atau kebangkrutan.

LPD di kabupaten Gianyar khususnya dengan aset Rp 3,6 triliun memiliki 270 LPD dengan kondisi yang beragam yaitu dengan ketegori sehat sebanyak 162 LPD, cukup sehat 40 LPD, kurang sehat 32 LPD, tidak sehat 7 LPD serta tidak beroperasional sebanyak 29 LPD. Tahun 2013 sampai 2017 terdapat 41 LPD yang mengalami masalah atau macet dan telah dapat dihidupkan kembali sebanyak 18 LPD. Dari uraian data tersebut diatas nampak telah banyak LPD di kabupaten Gianyar mengalami kebangkrutan. Oleh karenanya, perlu diadakan suatu analisis yang dapat menjelaskan dan memprediksi kebangkrutan agar pihakpihak terkait di kabupaten Gianyar dapat mengambil langkah-langkah atau strategi untuk menghindari kebangkrutan pada LPD di kemudian hari.

Tujuan penelitian ini yang hendak di capai adalah mengetahui LPD yang diprediksi mengalami kebangrutan menggunakan model grover, model zimjewski, model altman dan model manakah yang merupakan prediksi kebangkrutan yang terakurat pada LPD. Teori sinyal menekankan pentingnya informasi yang diberikan oleh pihak manajemen perusahaan kepada investor maupun pihak lain 
di luar perusahaan tentang bagaimana manajemen memandang prospek perusahaan, sehingga akan memberikan umpan balik dari investor atas informasi tersebut (Watts \& Zimmerman, 2000).

LPD adalah lembaga perkreditan yang diselenggarakan oleh pemerintah daerah, dimana pengelolaannya dilakukan oleh desa adat yang ada di Bali. Pengelolaan LPD tersebut sepenuhnya diserahkan kepada organisasi struktural dan fungsional yang ada di masing-masing desa pakraman, sedangkan penerimaannya disesuaikan dengan penerimaan dan pendapatan. LPD adalah salah satu lembaga desa yang merupakan unit operasional sebagai wadah kekayaan desa yang berupa uang tunai atau surat- surat berharga lainnya. Pemberdayaan LPD diarahkan kepada usaha-usaha peningkatan taraf hidup karma desa adat untuk menunjang pembangunan desa adat (Pemerintah Provinsi Bali, 2002).

Sejalan dengan pesatnya perkembangan yang terjadi dibidang keuangan dan LPD, oleh karena itu LPD wajib memelihara tingkat kesehatannya agar terus menerus dapat berkembang dan memberikan manfaat bagi masyarakat desa dan mendukung pembangunan desa pakraman. Penilaian kesehatan LPD dilaksanakan secara rutin tiga bulanan maupun secara insidentil atau sesuai dengan kebutuhan. Hasil penilaian kesehatan LPD disampaikan kepada pihak yang terkait untuk mendapatkan pembinaan guna memperbaiki kinerja LPD. Tingkat kesehatan LPD pada dasarnya dinilai dengan pendekatan kualitatif atas 5 faktor yaitu permodalan (capital), aktiva (assets), manajemen (management), rentabilitas (earning), dan likuiditas (liquidity).

Pernyataan Standar Akuntansi Keuangan (PSAK) Nomor 1 tentang Kerangka Dasar Penyususnan dan Penyajian Laporan Keuangan disebutkan bahwa tujuan laporan keuangan adalah menyediakan informasi yang menyangkut posisi keuangan, kinerja, serta perubahan posisi keuangan suatu perusahaan yang bermanfaat bagi sejumlah besar pemakai dalam pengambilan keputusan ekonomi. Laporan keuangan perusahaan merupakan salah satu sumber informasi yang penting disamping informasi lain. Disamping menggambarkan kondisi keuangan suatu perussahaan laporan keuangan juga dapat menilai kinerja manajemen perusahaan yang bersangkutan. Penilaian kinerja manajemen akan menjadi dasar apakah manajemen berhasil atau tidak dalam melaksanakan kebijakan yang telah ditentukan dalam bidang manajemen keuangan khususnya dan hal ini akan dapat tergambar dari laporan keuangan yang di susun oleh pihak manajemen.

Menurut Retnowulan dalam Darwis (2013) yang dimaksud dengan kepailitan adalah eksekusi massal yang ditetapkan dengan keputusan hakim, yang berlaku serta merta, dengan melakukn penyitaan umum atas semua harta orang yang dinyatakan pailit, baik yang ada pada waktu pernyataan pailit, maupun yang diperoleh selama kepailitan berlangsung, untuk kepentingan semua kreditur, yang dilakukan dengan pengawasan pihak yang berwajib.

Kebangkrutan adalah suatu kondisi disaat perusahaan mengalami ketidakcukupan dana untuk menjalankan usahanya. Menurut UU Kepailitan No. 4 Tahun 1998, perusahaan dinyatakan pailit berdasarkan pada keputusan pengadilan yang berwenang atau berdasarkan permohonan sendiri jika memiliki 2 atau lebih kreditur dan perusahaan tidak mampu membayar sedikitnya satu 
utangnya yang telah jatuh tempo. Ada beberapa istilah kebangkrutan yang digunakan menurut Brigham \& Gapenski (1996), yaitu: Economic failure, Business failure, Technical insolvency, Insolvency bankruptcy dan Legal bankruptcy.

Model grover merupakan model yang diciptakan dengan melakukan pendesainan dan penilaian ulang terhadap model altman. Sampel yang digunakan sebanyak 70 perusahaan dengan 35 perusahaan yang bangkrut dan 35 perusahaan yang tidak bangkrut pada tahun 1982 sampai 1996. Model Grover mengkategorikan perusahaan dalam keadaan bangkrut dengan skorkurang atau sama dengan $-0,02(Z \leq-0,02)$. Sedangkan nilai untuk perusahaan yang dikategorikan dalam keadaan tidak bangkrut adalah lebih atau sama dengan 0,01 $(\mathrm{Z} \geq 0,01)$.

Menurut Zmijewski (1984) model ini mengkritik metode pengambilan sampel yang digunakan pendahulu-pendahulunya. Sampel yang digunakan zmijewski berjumlah 840 perusahaan, terdiri dari 40 perusahaan yang mengalami kebangkrutandan 800 yang tidak mengalami kebangkrutan. Zmijewski menyatakan bahwa perusahaan bernilai positif $(X \geq 0)$ dianggap bangkrut dengan kata lain perusahaan bernilai negatif $(X<0)$ dianggap tidak bangkrut. Maka dari itu, nilai cutoff yang berlaku dalam model ini adalah 0 .

Altman adalah suatu alat yang digunakan untuk meramalkan tingkat kebangkrutan suatu perusahaan dengan menghitung nilai dari beberapa rasio yang kemudian dimasukkan dalam suatu persamaan diskriminan. Analisa ZScore ini telah dikembangkan pada tahun 1968 oleh Edward I. Altman. Dalam penelitiannya altman mengambil sample 66 perusahaan yang terdiri dari 33 perusahaan yang mengalami kebangkrutan selama 20 tahun belakangan dan 33 perusahaan yang dipilih acak yang tidak pernah mengalami kebangkrutan.

Model altman menggunakan rumus yang berbeda-beda sesuai dengan jenis perusahaan yaitu perusahaan manufaktur terbuka, perusahaan yang tertutup, dan perusahaan bukan manufaktur. Penelitian ini menggunakan rumus pada perusahaan bukan manufaktur dengan cut-off yang menyatakan perusahaan berada pada kondisi bangkrut jika nilai $Z<1,1$, perusahaan pada kondisi abu-abu jika nilai $Z$ diantara 1,1-2,60 $(1,1<Z<2,60)$, dan perusahaan pada kondisi tidak bangkrut jika nila $Z>2,60$.

Prihanthini and Sari (2013) dalam memprediksi kebangkrutan terhadap perusasahaan food and beverage menggunkan model grover tidak ada yang mengalami kebangkrutan. Fauzan and Sutiono (2017) dalam memprediksi kebangkrutan terhadap perbankan menggunkan model grover tidak ada yang mengalami kebangkrutan. Alam, et al (2016) dalam memprediksi kebangkrutan LPD di kecamatan Buleleng menggunakan model grover tidak ada yang mengalami kebangkrutan. Maka hipotesis yang diajukan yaitu:

$\mathrm{H}_{1}$ : Tidak terdapat LPD di kabupaten Gianyar yang diperdiksi bangkrut menggunakan model grover

Prihanthini and Sari (2013) dalam memprediksi kebangkrutan terhadap perusasahaan food and beverage menggunakan model zmijewski, terdapat perusahaan yang mengalami kebangkrutan. Fauzan and Sutiono (2017) dalam memprediksi kebangkrutan terhadap perbankan menggunkan model zmijewski, terdapat perbankan yang mengalami kebangkrutan. Alam, et al (2016) dalam memprediksi kebangkrutan terhadap LPD di kecamatan Buleleng menggunakan 
model zmijewski, terdapat LPD yang mengalami kebangkrutan. Maka hipotesis yang diajukan yaitu:

$\mathrm{H}_{2}$ : Terdapat LPD di kabupaten Gianyar yang diperdiksi bangkrut menggunakan model zmijewski.

Prihanthini and Sari (2013) dalam memprediksi kebangkrutan terhadap perusasahaan food and beverage menggunkan model altman, terdapat perusahaan yang mengalami kebangkrutan. Fauzan and Sutiono (2017) dalam memprediksi kebangkrutan terhadap perbankan menggunkan model altman, terdapat perbankan yang mengalami kebangkrutan. Alam, et al (2016) dalam memprediksi kebangkrutan terhadap LPD di kecamatan Buleleng menggunakan model altman, terdapat LPD yang mengalami kebangkrutan. Maka hipotesis yang diajukan yaitu:

$\mathrm{H}_{3}$ : Terdapat LPD di kabupaten Gianyar yang diperdiksi bangkrut menggunakan model altman.

Prihanthini and Sari (2013) menyatakan bahwa model grover merupakan model prediksi yang tepat digunakan dalam memprediksi kebangkrutan terhadap perusasahaan food and beverage. Fauzan and Sutiono (2017) dalam memprediksi kebangkrutan perbankan menyatakan bahwa model grover adalah model yang paling sesuai untuk diterapkan pada perusahaan perbankan yang go public. Aminian, et al. (2016) menyatakan bahwa model grover memiliki kemampuan yang lebih baik untuk memprediksi kebangkrutan daripada model altman, springate dan zmijewski.

$\mathrm{H}_{4}$ : Model grover merupakan model prediksi terakurat dan dapat digunakan memprediksi kebangkrutan pada LPD di kabupaten Gianyar.

\section{METODE PENELITIAN}

Metode penelitian yang digunakan dalam penelitian ini adalah penelitian deskriptif dengan jenis pendekatan studi kasus yaitu yang bertujuan untuk mengumpulkan data. Penelitian ini dapat menyajikan data dari laporan keuangan perusahaan, kemudian akan dilakukan analisis terhadap potensi kebangkrutan dengan menggunakan beberapa model prediksi kebangkrutan. Penelitian ini dilakukan untuk memprediksi kebangkrutan LPD di kabupatan Gianyar menggunkan model grover, zmijewski, dan altman.

Penelitian dilakukan pada LPD di wilayah kabupaten Gianyar. Pemilihan LPD kabupaten Gianyar sebagai lokasi penelitian dikarenakan kondisi dari LPD yang berada pada kabupaten ini bervariasi, ada dalam kondisi yang sehat, cukup sehat, kurang sehat, dantidak sehat. Obyek penelitian ini adalah laporan keuangan pada LPD di kabupaten Gianyar pada tahun 2013-2017 yang sudah dilaporakan kepada LPLPD yang terdiri dari neraca dan laporan laba rugi LPD yang khususnya berkaitan dengan permodalan, kualitas aktiva produktif, rentabilitas dan likuiditas.

Variabel dependen atau variabel terikat yang digunakan dalam penelitian ini adalah memprediksi kebangkrutan LPD. Variabel independen atau variabel bebas yang digunakan dalam penelitian ini adalah model grover, model zmijewski dan model altman. Data kuantitatif dalam penelitian ini yaitu berupa laporan keuangan dari LPD selama 5 tahun yaitu tahun 2013-2017. Sumber data yang digunakan dalam penelitian ini adalah data sekunder pada penelitian ini yaitu 
laporan keuangan lembaga yang didapat dari LPLPD dan daftar nama dan alamat LPD di kabupaten Gianyar. Populasi dalam penelitian ini adalah seluruh LPD di kabupaten Gianyar yaitu sebanyak 270 LPD. Teknik penentuan sampel yang digunakan dalam penelitian ini adalah sampel jenuh. Sampel jenuh merupakan adalah teknik penentuan sampel bila semua anggota populasi digunakan sebagai sampel namun dengan ketentuan sebagai berikut:

Tabel 1. Metode Penentuan Sampel

\begin{tabular}{ll}
\hline Keterangan & Jumlah \\
\hline LPD yang terdapat di kabupaten Gianyar & 270 LPD \\
LPD yang laporannya tidak lengkap & 46 LPD \\
Total LPD yang dijadikan sampel & 224 LPD \\
\hline
\end{tabular}

Sumber: Data Penelitian, 2018

Metode pengumpulan data yang digunakan dalam penelitian ini adalah metode dokumentasi. Metode pengumpulan data dalam penelitian ini dimaksudkan untuk memperoleh data yang relevan dan akurat dengan masalah yang dibahas. Metode dokumentasi yang digunakan dalam penelitian ini berbentuk tulisanya itu berupa laporan keuangan lembaga yang telah dilaporkan kepada LPLPD dari tahun 2013-2017, dari laporan keuangan tersebut peneliti dapat melihat indikator-indikator yang berhubungan dengan variabel yang akan diteliti. Indikator-indikator prediksi kebangkrutan dengan model grover, zmijewski, dan altman dapat dianalisis melalui laporan keuangan dan neraca.

Penelitian dimulai dengan pengumpulan data. Setelah data dikumpulkan, data diolah dan dianalisis untuk mengetahui kesimpulan akhir dari penelitian. Penelitian ini menggunakan tiga model analisis prediksi kebangkrutan yaitu model grover, model zmijewski, dan model altman. Adapun tahap-tahap analisis data dalam penelitian ini adalah dengan memperoleh data yang diperlukan yaitu laporan keuangan LPD di kabupaten Gianyar yang sudah dilaporkan kepada LPLPD 2013-2017. Mengkategorikan penilaian manajemen pada CAMEL yang sudah di analisis oleh LPLPD tahun 2013-2017 dan terdapat di laporan keuangan.

Menghitung nilai grover g-score dari rasio keuangan yang telah diketahui. Adapun rumus dari grover g-score adalah

Score $=1,650 \mathrm{X} 1+3,404 \mathrm{X} 2-0,016 \mathrm{ROA}+0,057$

Keterengan:

$\mathrm{X} 1=$ Working capital/Total assets

$\mathrm{X} 2$ = Earnings before interest and taxes/Total assets

$\mathrm{ROA}=$ Net income/Total assets

Melakukan interpretasi nilai hasil perhitungan model prediksi kebangkrutan grover, dimana $G \geq 0,01$ : LPD berada dalam keadaan sehat atau tidak berpotensi bangkrut dan $G \leq-0,02$ : LPD berada dalam keadaan potensial bangkrut.

Menghitung rasio keuangan perusahaan dengan model zmijewski, rasio keuangan yang dihitung mencakup rasio profitabilitas, rasio likuiditas, dan rasio leverage. Menghitung nilai zmijewski dari rasio keuangan yang telah diketahui. Adapun rumus dari zmijeski sebagai berikut:

$X=-4.3-4.5 \times 1+5.7 \times 2-0.004 X 3$.

Keterangan:

X1 = ROA (lababersih/total aset) 
$\mathrm{X} 2$ = Leverage (Total kewajiban/total aset)

X3 = Liquidity (aset lancar/kewajiban lancar)

Melakukan interpretasi nilai hasil perhitungan model prediksi kebangkrutan zmijewski, dimana $\mathrm{X}$ bernilai positif: LPD berada dalam keadaan potensial bangkrut dan $X$ bernilai negatif: LPD berada dalam keadaan tidak berpotensi bangkrut

Menghitung rasio keuangan perusahaan dengan model altman z-score, rasio keuangan yang dihitung mencakup rasio likuiditas, rasio profitabilitas, rasio solvabilitas dan rasio aktivitas. Menghitung nilai altman dari rasio keuangan yang telah diketahui. Adapun rumus dari altman z-score sebagai berikut:

$Z^{\prime \prime}=6,56(X 1)+3,26(X 2)+6,72(X 3)+1,05(X 4)$

Keterangan:

$\mathrm{X} 1=$ Modal Kerja $/$ Total Aset

X2 = LabaDitahan/Total Aset

X3 = LabaSebelumBunga Dan Pajak/Total Aset

X4 = Nilai Aktiva TetapTotal Kewajiban

Melakukan interpretasi nilai hasil perhitungan model prediksi kebangkrutan Altman Z-Score, dimana Z" < 1,1: LPD dalam kondisi berpotensi bangkrut (distress zone), 1,1 < Z" < 2,60: LPD dalam kondisi abu-abu (grey zone) dan Z" > 2,60: LPD dalam kondisi berpotensi tidak bangkrut (safe zone).

Menghitung tingkat akurasi dari masing-masing analisis model kebangkrutan dengan membandingkan hasil analisis penilaian manajemen pada CAMEL yang sudah dikategorikan. Tingkat akurasi dihitung untuk mengetahui model analisis prediksi kebangkrutan yang paling akurat dan tepat dalam memprediksi kebangrutan LPD di kabupaten Gianyar.

Tingkat Akurasi $=\frac{\text { Jumlah Prediksi Benar }}{\text { Jumlah Sample }} \times 100 \%$

Jumlah prediksi benar adalah jumlah prediksi dari hasil prediksi kebangkrutan yang sesuai dengan keadaan real perusahaan apakah mengalami kesulitan keuangan atau perusahaan mengalami kondisi keuangan yang sehat.

\section{HASIL PENELITIAN DAN PEMBAHASAN}

Uraian jumlah LPD di masing-masing kecamatan di kabupaten Gianyar yang termasuk dalam sampel sebagai berikut:

Tabel 2. LPD di kabupaten Gianyar yang dijadikan Sample

\begin{tabular}{lc}
\hline LPD di kabupaten Gianyar & Jumlah \\
\hline Kecamatan Blahbatuh & 32 \\
Kecamatan Gianyar & 33 \\
Kecamatan Payangan & 28 \\
Kecamatan Sukawati & 29 \\
Kecamatan Tampaksiring & 29 \\
Kecamatan Tegallalang & 42 \\
Kecamatan Ubud & 31 \\
Total & 224 \\
\hline
\end{tabular}

Sumber: Data Penelitian, 2018 
Analisis metode g-score pada model grover. Data Laporan Keuangan LPD di kabupaten Gianyar yang sudah dilaporkan dari tahun 2013-2017 dianalisis dengan g-score pada grover. Hasi dari nilai g-score yang sudah dianalisi dapat dikategorikan dalam kondisi mengalami kebangkrutan atau tidak mengalami kebangkrutan. Berdasarkan hasil analisis diperoleh dapat dilihat sebagai berikut:

Tabel 3. Hasil Analisis G-Score pada Model Grover

\begin{tabular}{ccccccc}
\hline \multirow{2}{*}{ Tahun } & \multicolumn{2}{c}{ Berpotensi Bangkrut } & \multicolumn{2}{c}{ Berpotensi Tidak Bangkrut } & \multicolumn{2}{c}{ Total } \\
\cline { 2 - 7 } & Jumlah & Persentase & Jumlah & Persentase & Jumlah & Persentase \\
\hline 2013 & 2 & $0,9 \%$ & 222 & $99,1 \%$ & 224 & $100 \%$ \\
2014 & 2 & $0,9 \%$ & 222 & $99,1 \%$ & 224 & $100 \%$ \\
2015 & 1 & $0,4 \%$ & 223 & $99,6 \%$ & 224 & $100 \%$ \\
2016 & 2 & $0,9 \%$ & 222 & $99,1 \%$ & 224 & $100 \%$ \\
2017 & 1 & $0,4 \%$ & 223 & $99,6 \%$ & 224 & $100 \%$ \\
\hline
\end{tabular}

Sumber: Data Penelitian, 2018

Berdasarkan tabel diatas diperoleh hasil analisis g-score pada model grover. Tahun 2013, 2014 dan 2016 adalah jumlah LPD yang diprediksi mengalami kebangkrut sebanyak 2 LPD dengan persentase 0,9\% dan LPD yang diprediski tidak mengalami kebangkrut sebanyak 222 LPD dengan persentase 99,1\%. Tahun 2015 dan 2017 adalah jumlah LPD yang diprediksi mengalami kebangkrut sebanyak 1 LPD dengan persentase $0,4 \%$ dan LPD yang diprediksi tidak mengalami kebangkrut sebanyak 223 LPD dengan persentase 99,6\%.

Metode $x$-score pada model zmijewski. Data Laporan Keuangan LPD di kabupaten Gianyar yang sudah dilaporkan dari tahun 2013-2017 dianalisis dengan $x$-score pada zmijewski. Hasi dari nilai $x$-score yang sudah dianalisi dapat dikategorikan dalam kondisi mengalami kebangkrutan atau tidak mengalami kebangkrutan. Berdasarkan hasil analisis diperoleh dapat dilihat sebagai berikut: Tabel 4. Hasil Analisis X-Score pada Model Zmijezwski

\begin{tabular}{ccccccc}
\hline \multirow{2}{*}{ Tahun } & \multicolumn{2}{c}{ Berpotensi Bangkrut } & \multicolumn{2}{c}{ Berpotensi Tidak Bangkrut } & \multicolumn{2}{c}{ Total } \\
\cline { 2 - 7 } & Jumlah & Persentase & Jumlah & Persentase & Jumlah & Persentase \\
\hline 2013 & 78 & $34,8 \%$ & 146 & $65,2 \%$ & 224 & $100 \%$ \\
2014 & 76 & $33,9 \%$ & 148 & $66,1 \%$ & 224 & $100 \%$ \\
2015 & 74 & $33,0 \%$ & 150 & $67,0 \%$ & 224 & $100 \%$ \\
2016 & 77 & $43,4 \%$ & 147 & $65,6 \%$ & 224 & $100 \%$ \\
2017 & 76 & $33,9 \%$ & 148 & $66,1 \%$ & 224 & $100 \%$ \\
\hline
\end{tabular}

Sumber: Data Penelitian, 2018

Berdasarkan tabel diatas diperoleh hasil analisis X-Score pada model zmijewski. Tahun 2013 jumlah LPD yang diprediksi mengalami kebangkrut sebanyak 78 LPD dengan persentase $34,8 \%$ dan LPD yang diprediksi tidak mengalami kebangkrut sebanyak 146 LPD dengan persentase 65,2\%. Tahun 2014 dan 2017 jumlah LPD yang diprediksi mengalami kebangkrut sebanyak 76 LPD dengan persentase 33,9\% dan LPD yang diprediksi tidak mengalami kebangkrut sebanyak 148 LPD dengan persentase 66,1\%. Tahun 2015 jumlah LPD yang diprediksi mengalami kebangkrut sebanyak 74 LPD dengan persentase 33,0\% dan LPD yang diprediksi tidak mengalami kebangkrutan sebanyak 150 LPD dengan persentase 67,0\%. Tahun 2016 jumlah LPD yang diprediksi mengalami kebangkrut sebanyak 77 LPD dengan persentase 43,4\% dan LPD yang diprediksi tidak mengalami kebangkrut sebanyak 147 LPD dengan persentase 65,6\%. 
Analisis metode $z$-score pada model altman. Data laporan keuangan LPD di kabupaten Gianyar yang sudah dilaporkan dari tahun 2013-2017 dianalisis dengan $z$-score pada altman. Hasi dari nilai $z$-score yang sudah dianalisi dapat dikategorikan dalam kondisi mengalami kebangkrutan atau tidak mengalami kebangkrutan. Berdasarkan hasil analisis diperoleh dapat dilihat sebagai berikut: Tabel 5. Hasil Analisis Z-Score pada Model Altman

\begin{tabular}{ccccccccc}
\hline \multirow{2}{*}{ Tahun } & \multicolumn{2}{c}{$\begin{array}{c}\text { Berpotensi } \\
\text { Bangkrut }\end{array}$} & \multicolumn{2}{c}{$\begin{array}{c}\text { Kondisi } \\
\text { Abu-Abu }\end{array}$} & \multicolumn{2}{c}{$\begin{array}{c}\text { Berpotensi } \\
\text { Tidak Bangkrut }\end{array}$} & \multicolumn{2}{c}{ Total } \\
\cline { 2 - 8 } & Jumlah & $\begin{array}{c}\text { Per- } \\
\text { sentase }\end{array}$ & Jumlah & $\begin{array}{c}\text { Per- } \\
\text { sentase }\end{array}$ & Jumlah & $\begin{array}{c}\text { Per- } \\
\text { sentase }\end{array}$ & Jumlah & $\begin{array}{c}\text { Per- } \\
\text { sentase }\end{array}$ \\
\hline 2013 & 0 & $0 \%$ & 0 & $0 \%$ & 224 & $100 \%$ & 224 & $100 \%$ \\
2014 & 0 & $0 \%$ & 0 & $0 \%$ & 224 & $100 \%$ & 224 & $100 \%$ \\
2015 & 0 & $0 \%$ & 0 & $0 \%$ & 224 & $100 \%$ & 224 & $100 \%$ \\
2016 & 0 & $0 \%$ & 0 & $0 \%$ & 224 & $100 \%$ & 224 & $100 \%$ \\
2017 & 0 & $0 \%$ & 0 & $0 \%$ & 224 & $100 \%$ & 224 & $100 \%$ \\
\hline
\end{tabular}

Sumber: Data Penelitian, 2018

Berdasarkan tabel diatas diperoleh hasil analisis $z$-score pada model altman. Tahun 2013 sampai tahun 2017 jumlah LPD yang diprediksi mengalami kebangkrut sebanyak 0 LPD dengan persentase $0 \%$. Kondisi grey zone atau kondisi abu - abu sebanyak 0 LPD dengan persentase $0 \%$, dan LPD yang berpotensi tidak bangkrut sebanyak 224 LPD dengan persentase $100 \%$.

Model grover dengan Penilaian Manajemen pada CAMEL. Menghitung tingkat akurasi dari model grover dengan peneliaian manajemen pada CAMEL. Tingkat akurasi dihitung untuk mengetahui model analisis prediksi kebangkrutan yang paling akurat dan tepat dalam memprediksi kebangrutan LPD di kabupaten Gianyar. Hasil akurasi model grover dengan penilaian manajemen pada CAMEL dapat di lihat sebagai berikut:

Tabel 6. Hasil Akurasi Model Grover dengan Penilaian Manajemen pada CAMEL

\begin{tabular}{cccc}
\hline Tahun & Prediksi Benar & Jumlah Sampel & Akurasi \\
\hline 2013 & 205 & 224 & $91,52 \%$ \\
2014 & 205 & 224 & $91,52 \%$ \\
2015 & 203 & 224 & $90,63 \%$ \\
2016 & 202 & 224 & $90,18 \%$ \\
2017 & 206 & 224 & $91,96 \%$ \\
& Rata - Rata & & $91,16 \%$ \\
\hline
\end{tabular}

Sumber: Data Penelitian, 2018

Berdasarkan tabel diatas diperoleh hasil akurasi model grover dengan peneliaian manajemen pada CAMEL dengan melakukan perbandingan sehingga mampu memprediksi kebangkrutan LPD. Tahun 2013 dan tahun 2014 mampu memprediksi benar 205 LPD dengan akurasi 91,52\%. Tahun 2015 memprediksi benar 203 LPD dengan akurasi 90,63\%. Tahun 2016 mampu memprediksi benar 202 LPD dengan akurasi 90,18\%. Tahun 2017 mampu memprediksi benar 206 LPD dengan akurasi $91,16 \%$. Berdasarkan pemaparan di atas maka rata-rata akurasi model grover dengan peneliaian manajemen pada CAMEL dalam memprediksi kebangkrutan LPD sebesar $91,16 \%$.

Akurasi model zmijewski dengan penilaian manajemen pada CAMEL. Menghitung tingkat akurasi dari model zmijewski dengan peneliaian manajemen 
pada CAMEL. Tingkat akurasi dihitung untuk mengetahui model analisis prediksi kebangkrutan yang paling akurat dan tepat dalam memprediksi kebangrutan LPD di Kabupaten Gianyar. Hasil akurasi model zmijewski dengan penilaian manajemen pada CAMEL dapat dilihat sebagai berikut:

Tabel 7. Hasil Akurasi Model Zmijewski dengan Penilaian Manajemen pada CAMEL

\begin{tabular}{cccc}
\hline Tahun & Prediksi Benar & Jumlah Sampel & Akurasi \\
\hline 2013 & 157 & 224 & $70,09 \%$ \\
2014 & 159 & 224 & $70,98 \%$ \\
2015 & 160 & 224 & $71,43 \%$ \\
2016 & 163 & 224 & $72,77 \%$ \\
2017 & 161 & 224 & $71,88 \%$ \\
& Rata - Rata & & $71,43 \%$ \\
\hline
\end{tabular}

Sumber: Data Penelitian, 2018

Berdasarkan tabel diatas diperoleh hasil akurasi model zmijewski dengan peneliaian manajemen pada CAMEL dengan melakukan perbandingan sehingga mampu memprediksi kebangkrutan LPD. Tahun 2013 mampu memprediksi benar 157 LPD dengan akurasi 70,09\%. Tahun 2014 mampu memprediksi benar 159 LPD dengan akurasi 70,98\%. Tahun 2015 mampu memprediksi benar 160 LPD dengan akurasi 71,43\%. Tahun 2016 mampu memprediksi benar 163 LPD dengan akurasi 72,77\%. Tahun 2017 mampu memprediksi benar 161 LPD dengan akurasi $71,88 \%$. Berdasarkan pemaparan di atas maka rata-rata akurasi model zmijewski dengan peneliaian manajemen pada CAMELdalam memprediksi kebangkrutan LPD sebesar 71,43\%.

Akurasi model altman dengan penilaian manajemen pada CAMEL. Menghitung tingkat akurasi dari model altman dengan peneliaian manajemen pada CAMEL. Tingkat akurasi dihitung untuk mengetahui model analisis prediksi kebangkrutan yang paling akurat dan tepat dalam memprediksi kebangrutan LPD di Kabupaten Gianyar. Hasil akurasi model altman dengan penilaian manajemen pada CAMEL dapat dilihat sebagai berikut:

Berdasarkan tabel 8 diperoleh hasil akurasi model altman dengan peneliaian manajemen pada CAMEL dengan melakukan perbandingan sehingga mampu memprediksi kebangkrutan LPD. Tahun 2013, 2014 dan 2017 mampu memprediksi benar 207 LPD dengan akurasi 92,41\%. Tahun 2015 dan 2016 mampu memprediksi benar 204 LPD dengan akurasi 91,07\%.

Tabel 8. Hasil Akurasi Model Altman dengan Penilaian Manajemen pada CAMEL

\begin{tabular}{cccc}
\hline Tahun & Prediksi Benar & Jumlah Sampel & Akurasi \\
\hline 2013 & 207 & 224 & $92,41 \%$ \\
2014 & 207 & 224 & $92,41 \%$ \\
2015 & 204 & 224 & $91,07 \%$ \\
2016 & 204 & 224 & $91,07 \%$ \\
2017 & 207 & 224 & $92,41 \%$ \\
& Rata - Rata & & $91,87 \%$ \\
\hline
\end{tabular}

Sumber: Data Penelitian, 2018 
Berdasarkan pemaparan di atas maka rata-rata akurasi model altman dengan peneliaian manajemen pada CAMEL dalam memprediksi kebangkrutan LPD sebesar $91,87 \%$.

Hasil analisis akurasi kebangkrutan LPD. Tingkat akurasi digunakan untuk mengetahui model analisis prediksi kebangkrutan yang paling akurat dan tepat dalam memprediksi kebangrutan LPD di kabupaten Gianyar. Rangkuman tingkat akurasi dari ketiga model dapat dilihat sebagai berikut:

Tabel 9. Rangkuman Tingkat Akurasi Model

\begin{tabular}{cccc}
\hline Tahun & Grover & $\begin{array}{c}\text { Tingkat Akurasi } \\
\text { Zmijewski }\end{array}$ & Altman \\
\hline 2013 & $91,52 \%$ & $70,09 \%$ & $92,41 \%$ \\
2014 & $91,52 \%$ & $70,98 \%$ & $92,41 \%$ \\
2015 & $90,63 \%$ & $71,43 \%$ & $91,07 \%$ \\
2016 & $90,18 \%$ & $72,77 \%$ & $91,07 \%$ \\
2017 & $91,96 \%$ & $71,88 \%$ & $92,41 \%$ \\
Rata - Rata & $91,16 \%$ & $71,43 \%$ & $91,87 \%$ \\
\hline
\end{tabular}

Sumber: Data Penelitian, 2018

Berdasarkan tabel diatas diperoleh rata-rata akurasi model grover sebesar 91,16\%. Rata - rata tingkat akurasi model zmijewski sebesar 71,43\%. Rata - rata tingkat akurasi model altman sebesar $91,87 \%$. Sehingga urutan tingkat akurasi dari tertinggi ke terendah adalah model altman, grover, dan zmijewski.

Berdasarkan hasil analisis g-score pada model grover diperolehpada tahun 2013, 2014 dan 2016 terdapat 2 LPD yang diprediksi mengalami kebangkrutan. Tahun 2015 dan tahun 2017 terdapat 1 LPD yang diprediksi mengalami kebangkrutan. Potensi kebangkrutan tersebut terjadi karena g-score yang dimiliki LPD berada dibawah skor $-0,02$.

Hasil tersebut berlawan dengan hasil penelitian yang dilakukan oleh Prihanthini and Sari (2013) dalam memprediksi kebangkrutan terhadap perusasahaan food and beverage menggunkan model grover tidak ada perusahaan yang diprediksi mengalami kebangkrutan. Fauzan and Sutiono (2017) dalam memprediksi kebangkrutan terhadap perbankan menggunkan model grover tidak bank yang diprediksi mengalami kebangkrutan. Alam, et al (2016) dalam memprediksi kebangkrutan LPD di kecamatan Buleleng menggunakan model grover tidak ada LPD yang diprediksi mengalami kebangkrutan. Hasil penelitian ini di dukung dengan hasil penelitian Kurniawati et al. (2016) dalam memprediksi Bank Syariah di Indonesia menggunakan model grover terdapat perusahaan yang diprediksi mengalami kebangkrutan.

Berdasarkan hasil analisis $x$-score pada model zmijewski diperoleh pada tahun pada tahun 2013 terdapat 78 LPD diprediksi mengalami kebangkrut. Tahun 2014 dan tahun 2017 terdapat 76 LPD diprediksi mengalami kebangkrut. Tahun 2015 terdapat 74 LPD diprediksi mengalami bangkrut. Tahun 2016 terdapat 77 LPD diprediksi mengalami bangkrut. Hal tersebut menunjukan bahwa terdapat LPD yang memperoleh $x$-score kurang dari 1,1.

Hasil tersebut senada dengan hasil penelitian yanag dilakukan oleh Prihanthini and Sari (2013) dalam memprediksi kebangkrutan terhadap perusahaan food and beverage menggunkan model zmijewski, terdapat perusahaan yang diprediksi mengalami kebangkrutan. Fauzan and Sutiono (2017) dalam 
memprediksi kebangkrutan terhadap perbankan menggunkan model zmijewski, terdapat bank yang diprediksi mengalami kebangkrutan. Alam, et al (2016) dalam memprediksi kebangkrutan terhadap LPD di kecamatan Buleleng menggunakan model zmijewski, terdapat LPD yang diprediksi mengalami kebangkrutan.

Berdasarkan hasil analisis z-score pada model altman diperoleh bahwa tidak terdapat LPD yang diprediksi berpotensi mengalami kebangkrutan pada tahun 2013-2017. Hasil tersebut berlawannan dengan penelitian yang dilakukan oleh Prihanthini and Sari (2013) dalam memprediksi kebangkrutan terhadap perusasahaan food and beverage, terdapat perusahaan yang diprediksi mengalami kebangkrutan. Fauzan and Sutiono (2017) dalam memprediksi kebangkrutan terhadap perbankan terdapat bank yang diprediksi mengalami kebangkrutan. Alam, et al (2016) dalam memprediksi kebangkrutan terhadap LPD di kecamatan Buleleng diprediksi mengalami kebangkrutan menggunakan model Altman.

Hasil penelitian ini didukung oleh Sagho \& Merkusiwati (2015) tidak terdapat bank yang diprediksi mengalami kebangkrutan menggunakan model altman. Berdasarkan hasil analisis data diperoleh rata-rata akurasi model grover sebesar $91,16 \%$. Rata - rata tingkat akurasi model zmijewski sebesar 71,43\%. Rata - rata tingkat akurasi model altman sebesar 91,87\%. Demikian urutan tingkat akurasi tertinggi ke terendah adalah model altman, model grover, dan model zmijewski. Hasil ini menunjukan hasil model-model kebangkrutan yang telah diinterpretasikan dengan penilaian manajemen pada CAMEL tersebut menunjukan bahwa semakin tinggi akurasi model maka semakin baik pula model memprediksi potensi kebangkrutan LPD.

Hasil tersebut tidak sesuai dengan penelitian yang dilakukan oleh Prihanthini and Sari (2013) menyatakan bahwa model grover model prediksi yang tepat digunakan dalam memprediksi kebangkrutan terhadap perusasahaan food and beverage. Fauzan and Sutiono (2017) dalam memprediksi kebangkrutan perbankan menyatakan bahwa model grover adalah model yang paling sesuai untuk diterapkan pada perusahaan perbankan yang go public. Aminian, et al. (2016) dalam memprediksi kebangkrutan terhadap saham di Tehran menyatakan bahwa model grover memiliki kemampuan yang lebih baik untuk memprediksi kebangkrutan.

Hasil penelitian ini di dukung dengan hasil penelitian Sagho \& Merkusiwati (2015) dalam memprediksi kebangkrutan terhadap bank yang terdaftar di BEI. Primasari (2017) dalam memprediksi kebangkrutan terhadap perusahaan industry barang-barang konsumsi. Hasil penelitian Sagho \& Merkusiwati (2015) dan Primasari (2017) menyatakan model altman dapat dan akurat digunakan dalam memprediksi kebangkrutan. Demikian dengan hasil rata - rata tingkat akurasi model altman sebesar 91,87.

\section{SIMPULAN}

Berdasarkan hasil analisis penelitian dan hasil pembahasan pada bab sebelumnya maka simpulan dari penelitian ini adalah model grover memprediksi, terdapat LPD yang diprediksi yang mengalami kebangkrutan pada tahun 2013, 2014 dan 2016 sebanyak 2 LPD. Tahun 2015 dan 2017 terdapat 1 LPD yang diprediksi mengalami kebangkrutan. Hal tersebut menunjukan $g-$ 
score $<-0,02$. Model zmijewski memprediksi, terdapat LPD yang diprediksi yang mengalami kebangkrutan pada tahun 2013 sebanyak 78 LPD. Tahun 2014 dan 2017 terdapat 76 LPD yang diprediksi mengalami kebangkrutan. Tahun 2015 terdapat 74 LPD yang diprediksi mengalami kebangkrutan. Tahun 2016 terdapat 77 LPD yang diprediksi mengalami kebangkrutan. Hal tersebut menunjukan $x$ score $<0$. Model altman memprediksi tidak terdapat LPD yang diprediksi yang mengalami kebangkrutan dari tahun 2013-2017. Hal tersebut menunjukan zscore $>2,60$. Model altman memiliki tingkat akurasi tertinggi dalam memprediksi potensi kebangkrutan LPD. Adapun urutan tingkat akurasi tertinggi ke terendah adalah model altman, grover dan zmijewski.

Berdasarkan hasil penelitian dan simpulan, maka sarannya adalah bagi peneliti selanjutnya, hasil penelitian ini diharapkan mampu dijadikan sebagai kajian pustaka untuk melakukan penelitian terkait. Diharapkan peneliti dalam penelitian selanjutnya dapat menggunakan analisis potensi kebangkrutan lain yang telah ditemukan seperti Springrate, Ohlson, Shirata, Ca Score, dan Fulmer memperpanjang waktu pengamatan, dan menambah jumlah sampel perusahaan sehingga hasil yang diberikan dapat mengeneralisasi penelitian.

Bagi masyarakat desa pakraman, hasil penelitian ini dapat digunakan sebagai acuan untuk membantu memutuskan dalam menyimpan dana dan meminjam data di LPD khususnya LPD di kabupaten Gianyar, agar mehindari terjadinya kehilanggan dana. Bagi LPLPD dan manajemen LPD kabupaten Gianyar, hasil penelitian ini dapat digunakan sebagai dasar dalam menentukan langkah untuk menilai kondisi keuangan internal LPD. Hal tersebut dapat dilakukan dengan cara mengaplikasikan model altman dalam mengevaluasi keadaan keuangan internal LPD. Pihak manajemen LPD hendaknya lebih melengkapi laporan keuangan tahunan.

\section{REFERENSI}

Adi Lazuardi. (2018). 'Laba LPD Gianyar Capai Rp83 Miliar', Antaranews Bali, 24 Januari 2018, website: https://bali.antaranews.com/berita/124754/labalpd-gianyar-capai-rp83-miliar

Alam, I. S., Suwendra, I. W., \& Yulianthini, N. N. (2016). Analisis Prediks Kebangkruutan dengan Menggunakan Metode G-Score, X-Score, dan ZScore pada Lembaga Perkreditan Desa di Kecamatan Buleleng Periode 20132014. E-Journal Bisma Universitas Pendidikan Ganesha, 4.

Altman, E. I. and Hotchkiss, E. (2006). 'Corporate Financial Distressand Bankruptcy $3 r d$ Edition', Jon Wiley \& Sons Inc., New Jersey

Aminian, A., Mousazade, H., \& Khoshkho, O. I. (2016). Investigate the Ability of Bankruptcy Prediction Models of Altman and Springate and Zmijewski and Grover in Tehran Stock Exchange. Mediterranean Journal of Social Sciences, 7(4), 208-214. https:/ / doi.org/10.5901/mjss.2016.v7n4s1p208

Bali, P. P. (2002). Pemerintah Provinsi Bali.

Brigham, E. F., \& Gapenski, L. (1996). "Intermadiate finance management" (5th ed.). Harbor Drive: The Dryden Press.

Darwis, R. (2013). Analisis Laporan Keuangan untuk Memprediksi Kebangkrutan Perusahaan dengan Membandingkan Model Altman Z- Score dan Model Springate pada Perusahaan Manufaktur Makanan dan Minuman 
yang Terdaftar Di Bursa Efek Indonesia. Universitas Sumatera Utara.

Fauzan, H., \& Sutiono, F. (2017). Perbandingan Model Altman Z- Score, Zmijewski , Springate, dan Grover Dalam Memprediksi Kebangkrutan Perusahaan Perbankan (Studi Kasus pada BEI Tahun 2011-2015). Jurnal Online Insan Akuntan, 2(1), 49-60.

Kurniawati, Lintang, \& Kholis, N. (2016). Analisis Model Prediksi Financial Distress pada Perusahaan Perbankan Syariah di Indonesia. Syariah Paper Accounting FEB UMS.

Peraturan Daerah Provinsi Bali. (2017). Peraturan Daerah Provinsi Bali Nomor 3 Tahun 2017 tentang Lembaga Perkreditan Desa Sebagai Mana Telah Diubah Beberapa Kali Terakhir dengan Peraturan Provinsi Bali tentang Perkreditan Desa.

Prihanthini, N. M. E. D., \& Sari, M. M. R. (2013). Prediksi Kebangkrutan dengan Model Grover, Altman Z-Score, Springate dan Zmijewski pada Perusahaan Food and Beverage di Bursa Efek Indonesia. E-Jurnal Akuntansi Universitas Udayana, 2, 417-435.

Primasari, N. S. (2017). Analisis Altman Z-score, Grover Score, Springate, dan Zmijewski sebagai Signaling Financial Distress (Studi Empiris Industri Barang-Barang Konsumsi Indonesia). Accounting and Management Journal, 1(1), 23-43.

Ramantha, I W. 2006. 'Menuju LPD Sehat', Buletin Studi Ekonomi, 11(1)

Sagho, M., \& Merkusiwati, N. (2015). Penggunaan Metode Altman Z-score Modifikasi Untuk Memprediksi Kebangkrutan Bank Yang Terdaftar Di Bursa Efek Indonesia. E-Jurnal Akuntansi, 11(3), 730-742.

Sari, M. P. and Yunita, I. (2019). 'Analisis Prediksi Kebangkrutan dan Tingkat Akurasi Model Springate, Zmijewski, dan Grover pada Perusahaan Sub Sektor Logam man Mineral Lainnya yang Terdaftar Di Bursa Efek Indonesia Tahun 2012-2016', Jurnal Ilmiah Manajemen Universitas Putera Batam, 7(1), pp. 69-77.

Watts, R. L., \& Zimmerman, J. L. (2000). Positive Accounting Theory: A Ten Year Perspective. The Accounting Review, 65(1), 131156.

Zmijewski, M. (1984). Methodological Issues Related to the Estimation of Financial Distress Prediction Models. Journal of Accounting Research. Supplement, 22, 59-82. 